\title{
THE IMPACT OF INFLATION ON SOME
} MACROECONOMICS INDICATORS IN SUDAN DURING THE PERIOD (1990 - 2018)

Ali E.M. Nour Zaroog ${ }^{1}$; M.K. A.Mohammed ${ }^{2}$ and O.E.M.Nasir ${ }^{3}$

1. Associate Professor in Economics Department - University of Bakht-erruda.

2. Assistant Professor in Econometrics and Social Statistic Department University of Bakht-erruda.

3. Assistant Professor in Econometrics and Social Statistic Department University of Bakht-erruda.

Key Words: Inflation, Money Supply, Exchange Rate, Economic Growth, and Unemployment.

\section{ABSTRACT:}

The study aimed to examine the effect of inflation on some macroeconomics indicators in Sudan during the period (1990-2018). By focusing on the most important macro variables (money supply, exchange rate, and economic growth). The most important assumptions of the study is that there is an inverse relationship between inflation and the growth rate of the Sudanese economy represented in the gross domestic product, and positive relationship between the money supply and the deterioration of the exchange rate level. The study used the descriptive, statistical, and econometric method MANAVO over the SPSS program. The most important results proved the study hypotheses, that there is a positive relationship between inflation, money supply and exchange rate deterioration, and an inverse relationship with GDP in Sudan. The study recommended the necessity of adopting macroeconomic policies concerned with the productive sectors in order to combat the continuous rise in prices and improve the level of the exchange rate in Sudan.

\section{INTRODUCTION:}

High and sustained economic growth with low inflation is the central objective of the macroeconomic policy makers. Therefore, inflation has been one of the most researched topics in macroeconomics for the last many years because it has serious implications for growth and income distribution (Mohammed, et al., 2011). The argument of inflation hinges on two premises: in times of fixed nominal interest rates, higher inflation expectations decrease real interest rates (see Fisher equation), and lower real interest rates reduce savings and stimulate consumption (see Euler equation). However, the effect of real interest rates on consumption depends on assumptions regarding preferences. In addition, households use paper money as a medium of exchange. Higher inflation is an implicit tax on paper money, and could lower economic activity. Higher inflation might also increase inflation uncertainty, and 
reduce consumption spending via a precautionary savings channel (Francesco, et al., 2015). Price stability is considered as the key variable to promote economic growth as well as sustainable development. The major objective for many central banks is to maintain price stability with high growth rates. As money loses its value people lose confidence in it as a medium of exchange. The resulting effect is a fall in savings and consequently lower investment as well as economic growth (Tutoru, 2009). Inflation was the result of weak economic and financial policies, including considerable financial (monetary and fiscal) expansion, severe import compression, extensive price and wage controls, rationing, high subsidies, and constraints on the private sector. These policies resulted in a large and active parallel market for goods and services and foreign exchange, and a surge of inflation which averaged 40 percent in the first half of the 80s only to accelerate thereafter, reaching 130 percent in 1991 and 140 percent in 1992 in Sudan. Sudan annual inflation climbed to record a high of 166.8 in August 2020. Main pressure came from food and fuel prices, aggravated by months-long Corona virus lockdown measures. Inflation has been rising in recent years amid persistent shortage of bread, beverages and fuel, as black market for US dollars. This study tried to aimed to examine the effect of inflation on some macroeconomics indicators in Sudan during the period (1990-2018).

\section{Problem Statement:}

Much of the empirical literature looks for a negative influence of inflation on macroeconomics variables. Inflation reduces the purchasing power of each unit of currency because it leads to increase in prices. Increase in inflation rates indicates an accelerating deterioration in economics activities and sectoral production. It leads to lower levels of investment, economic growth and impact the balance of payments by making its exports relatively more costly. Moreover, inflation can interact with the tax system to disturb borrowing and lending decisions.

\section{Objectives Of the Study:}

The study depends on the following objectives:

1. To examine the impact and relationships of inflation on GDP growth, money supply, and exchange rate in Sudan.

2. To explore the GDP growth performance and the historical trends of inflation in Sudan.

3. To study the polices implications that have been applied in Sudan during the period of study.

\section{Hypothesis of the Study:}

The hypothesis that pinned this study is that:

1. Inflation is negatively related to economic growth in Sudan.

2. There has been a positive relationship between inflation rate and the deterioration in exchange rate in Sudan. 
3. The inflation rate related positively to money supply in Sudan.

\section{Methodology and Data Collection:}

GARCH-M estimation technique has been used in this study to estimate the model, whereas the sources of data were primarily based on secondary data for the period (1980-2018). The methodology and variables for the study have been selected the relative importance on theoretical and empirical basis. It is also attempted to include the variables which mostly determine the level and rate of economic growth in Sudan. Annual time series data for this study have been collected from the Ministry of Finance and Economic Planning Scurvies and Bank of Sudan reports for the period 1980-2018.

\section{Literature Reviews:}

Most of economists use the background of the civil war in Sudan to analyze the Sudanese economic decline in the last three decades. But a little focus upon the situation can shows that the civil war was not the main reason of the decline, as although it may be considered as one of the decline factors, but the real reason is the economic policies of the Sudanese governments which were assumed to be the principles director of the economic regulations (Almosharaf and Fung, 2014).

Khan and Senhadji (2001), examine the effects of inflation on growth separately for industrial and developing countries. The data set covers 140 countries from both groups and non-linear least squares (NLLS) and conditional least squares methods are used. The empirical results verify the existence of a threshold beyond which inflation exerts a negative effect on growth. Significant thresholds at 1-3 percent and 11-12 percent inflation levels for industrialized and developing countries have been found. The view of low inflation for sustainable growth is strongly supported by the study.

The negative effects of inflation have been studied in the context of models of economic growth in which the continuous increase of per capita income is the outcome of capital accumulation along with technological progress. The uncertainty associated with high and volatile unanticipated inflation has been found to be one of the main determinants of the rate of return on capital and investment (Bruno, Pindyck and Solimano 1993).

Fisher (1993), has investigated relationship between inflation and economic growth for 93 countries. He used data set consisting of several macroeconomic variables including inflation. He has found out that the inflation negatively affected growth by reducing investment, and by reducing rate of productivity growth.

Mukoka (2018), examined the impact of inflation on economic growth in Zimbabwe. The time series yearly data for inflation and economic growth (GDP) from 1990 to 2017 were used for the study. 
Ordinary Least Squares (OLS) was used to determine the impact of inflation on Economic growth. There was also evidence of co integration between the two variables using the Johansen Co integration Test. The results of the study established no relationship between Inflation and Gross Domestic Product in Zimbabwe. In this regard the study concluded that all factors which cause an increase in the general price levels such as energy (petrol, diesel, gasoline, and paraffin), exchange rates volatility, increase in money supply, poor agricultural production and so forth, should be kept on check, with the appropriate policies so as to foster economic growth.

Kormendi and Meguire (1985), estimated a growth equation with cross section data and find that the effect of inflation on the growth rate is negative, although it loses explanatory power when the rate of investment is also included in the regression.

The negative effects of inflation have been studied in the context of the models of economic growth (Orphanides and Solow (1990), De Gregorio (1993) and Roubini and Martín (1995)). The continuous increase of per capita income is the outcome of capital accumulation and the continuous improvement in the efficiency with which productive factors are used.

Michael Sarel (1995), examined the possibility of nonlinear effects of inflation on economic growth. It finds evidence of a significant structural break in the function that relates economic growth to inflation. The break is estimated to occur when the inflation rate is 8 percent. Below that rate, inflation does not have any effect on growth, or it may even have a slightly positive effect. When the inflation rate is above 8 percent, however, the estimated effect of inflation on growth rates is significant, robust and extremely powerful.

According to Francesco, et al., (2015), households that expect an increase in inflation have an $8 \%$ higher reported readiness to spend on durables compared to other households. This positive cross sectional association is stronger for more educated, working age, high income, and urban households. They were documented these novel facts using German micro data for the period 2000-2013. The German government unexpectedly announced in November 2005 a three percentage point increase in value added tax (VAT) effective in 2007. This shock increased households' inflation expectations during 2006, as well as actual inflation in 2007.

Martin, et al,. (2011), found a positive relationship between real exchange rate RER under valuation and economic growth. Different rationales for this association have been offered, but they all imply that the mechanisms involved should be stronger in developing countries. Rodrik (2008) explicitly analyzed and found evidence that the growth 
relationship is more prevalent in developing countries. They were showed that his finding is very sensitive to the criterion used to divide the sample between developed and developing countries. They were used alternative classification criteria and empirical strategies to evaluate the existence of asymmetries between groups of countries and found that the effect of currency undervaluation on growth is indeed larger and more robust for developing economies. However, the relationship between RER undervaluation and per capita GDP is non monotonic.

Evans and Antwi1, (2013), the main objective of their study was to investigate the effect that changes in the inflation and interest rates have on the Gross Domestic Product (GDP) in Ghana for the period 1980-2010. The study employed multiple linear regressions to establish that there exists a fairly strong positive correlation between GDP, Interest rate and

Inflation, but Inflation and Interest rate could only explain movement in GDP by only 44 percent. They were established that, there existed positive relationship between inflation and GDP and interest rate is negative. It is recommended among others that the Government together with the Bank of Ghana should develop and pursue prudent monetary policies that would aim at reducing and stabilizing both the micro and macroeconomic indicators such as inflation targeting, interest rate, so as to boast the growth of the economy.

Mashehdul Islam (2009), considered the relationships between exchange rate and inflation and between exchange rate and GDP in Bangladesh. Bangladesh experiences of moving away from a currency board system to floating regime since 2003 offers a lesson worthy of attention from the point of view of efficiency of Floating Rate System in least developed countries like Bangladesh. Floating exchange rate regime in Bangladesh contrasts with its neighbor's currency board system. Experiences in Bangladesh and abroad show that all that a government needs in this regard is to maintain confidence in the currency, secure currency's strength and ensure its full convertibility. As long as this is backed by sufficient reserve of the foreign exchanges and there is firm political and economic will, adoption of a successful free exchange rate regime is possible.

Zaroog (2013) attempted to examine the behavioral macroeconomic functions, and the interactions between macroeconomics variables and its affect on economic growth and macroeconomics policies stability for the period 1970-2005. In this study the three stage least squares used simultaneously as estimation technique for the period 1970-2005. The results of estimated equations showed that, all equations were statistically significant. Also results showed that there was instability in Sudan economy during the periods 1979- 81 and 1996-95. 
Also the complex conditions of natural disasters, civil wars, instability of governance, and the external political and economical pressures aggravated the Sudan economy situation. Elhussein and Abdalla (2018), investigated the determinants of exchange rate in Sudan and assess their impact on its volatility. Their paper used the ARDL model to study the relationship between the dependent and independent variables. Their study documented that, the determinant factors of the exchange rate in Sudan are the balance of trade, gold purchases, money supply, inflation and foreign reserves. The continuous deterioration and fluctuation in exchange rate throughout the period under study suggest that the exchange rate system followed has no impact on the stability of the exchange rate

\section{Sudan Economy Background:}

The civil war took place in Sudan casted a negative effect on Sudan economy over years. It considered as part of the resource curse but it is not considered as a direct cause of the economic deterioration. There are many other factors lead to the tragic situation, one of the most important factors the instability of the political situation over the past fifty years and inappropriate economic policies in Sudan (Almosharaf and Tian, 2014).

In early 1960 s, economic activities controlled by the government, in 1970s, and mid-1980s economic strategy dominated the development policy (Ali, 1985). In 1979, Sudan adopted macroeconomic stabilization and structural adjustment programs recognized by the IMF and the World Bank. However, the economy continued to decline further during 197884. The annual economic growth rate dropped to $1.7 \%$, and macroeconomics continued its deterioration. The inflation rate increased to more than $27 \%$; to indicate the inefficiency of monetary policy pursued in Sudan. The performance of the economy in 1980s was weak due to the increased cost of the South Sudan war, which increased the budget deficit. The external finance and the use of counterpart funds for foreign aid covered about $60 \%$ of the total debt, leading to greater dependence on foreign aid. Money supply increased as the annual rate of monetary expansion reached about 40\% during 1981-1985 (Hag Elamin \& Elmak, 1997 and Tomader, 2012).

The Sudanese government adopted a number of development plans. These plans included the Ten Year Plan (1960-1970), the Five Year Plan (1970-1975), the Amended Five Year Plan (1970-1977), the Six Year Plan (1977-1982), the first Three Year Public Investment Program (19791982), the second Three Year Public Investment Program (1982-1985), the Four Year Salvation, Recovery and Development Program (19881992) and the Three Year National Economic Salvation Program (1990- 
1993), and the Comprehensive National Strategy covering the period (1992-2002), (Abdulrahman, 2013).

The exploitation of oil since 1999 has created a remarkable shift in the structure of the Sudanese economy, from predominantly reliant on agriculture for growth and exports, to reliance on the oil sector. Because of oil Sudan experienced its longest and strongest period of growth since independence where the size of economy, in terms of its GDP, grown substantially with real GDP growth rate averaged nearly 8 percent during the nine year period ending in 2008. The strong economic expansion generated by oil has, however, been unbalanced as, the inherited regional inequality and disparity in services provision remains striking while exports of key products have fallen in large part because of reduced competitiveness, leading to economic growth and the country remains having a substantial external debt amounted to about US $\$ 43.2$ billion in nominal terms (more than 70 percent of GDP) in 2012 .Although data gaps are substantial it is believed that the majority of those who are economically active are involved in the informal economy activities (United Nations Development Assistance Framework UNDAF, 20092012).

Inflation rates have fallen to very low levels of $8 \%$ in 2000 , after it was $166 \%$ in 1996 , a significant stability had took place in exchange rate, and the rate of GDP growth returned to rise to reach an average of about $6 \%$ during 1997-2000. This situation had made improving and some sort of relative stability in the Sudanese economy until the year 2008, in spite of internal political crises that took place in Sudan, the level of external relations, and Darfur crisis. Due to the budget deficit caused by the loss of oil revenues on the one hand (2011), the decline in agricultural and industrial production on the other hand, and because of total reliance on oil without hiring the proceeds for the benefit of the productive sectors, the inflation rate started raising until it reach in August 2012, more than $41.6 \%$. The thing which clearly seen in the uncontrollable rising of the price levels, it also led to a decline equivalent to $45 \%$ in the monetary value, which led to the capital erosion in addition to decline in private sector investments due to the fears of instability and economic imbalance (Almosharaf and Tian, 2014).

Gold export by the Republic of Sudan has recently become the major foreign exchange earner following the secession of the southern part of the country and the creation of the Republic of South Sudan in July 2011. With most of the oil fields located in the south, the new state took more than $75 \%$ of the oil production capacity of the former unified country. However, by 2012, just one year after the secession, Sudan became Africans' third largest gold producer after South Africa and Ghana and among the top 15 global gold miners. It is not surprising, 
therefore, that gold export has displaced oil export contributing 33\% average in 2012-2017 (Elbadawi and Kabbashi, 2018).

In nineteen nineties the government announced the economic liberalization policy during which market mechanism is selected as a tool for setting exchange rates. During the period 2000-2006 and as a result of foreign currency inflows associated with Sudan petroleum exports, the foreign exchange market was unified with a sole exchange rate of 2.6 Sudanese pounds for the dollar. The exchange rate kept on deteriorating at an accelerating rate throughout the period 2006-2017, from 2.6 to 6.9 US dollars, with many interventions and devaluations of currency by the central bank. For instance in 2012 the Sudanese pound was devalued by $91 \%$ in one step, from 2.67 to 4.42 pounds for the dollar to minimize the difference between the official and parallel rate. Nevertheless the problem continues and the difference between the parallel and official exchange rates continued to escalate to reach 184 percent of the parallel rate by the end of 2017 (Elhussein and Abdalla, 2018).

Since late 2011, Sudan has observed remarkable decrease in economic growth, which increased inflation and unemployment rates. Since then, Sudan underwent economic reforms that favored adopt stabilization policies. Considering that the ongoing Five Year Economic Reform Plan (2015-2018) for growth and poverty reduction cannot be achieved unless stabilized the macroeconomic indicators. Economic recovery continues to elude Sudan. The absence of proper strategies, economic reform and lack of fiscal and monetary policies have now resulted in low levels of per capita income, where a majority of labor force involved in agricultural activities. Addressing these require structural transformation to high productivity levels and focusing on long-term sustainable sources for economic growth and inclusive development, and move towards agro-processing industries (Elryah, 2016).

At the start of 2018, the economic situation severely worsened due to a set of economic restructuring reforms to access foreign exchange and governmental funds as recommended by the International Monetary Fund (IMF). Among other changes, the government cut wheat and fuel subsidies and devaluated the Sudanese pound (SDG) several times; from 6.7 SDG/USD to 30 SDG/USD in February 2018, and to 47.5 SDG/USD in October 2018. Exchange rates on the parallel market, often the only available trade, rose to $70 \mathrm{SDG} / \mathrm{USD}$ in the end of 2018, restricting foreign trade even further. The shortage of hard currency intensified, adding to rising inflation rates which reached $72.9 \%$ in December 2018, a severe increase compared to $25 \%$ in 2017 . In sum, high inflation rates combined with high external debts, declining national GDP, and the rapid depreciation of hard currency, decreased the private sector's and the 
government's ability to import necessary commodities such as fuel, wheat and medicines. However, cuts in the security spending are not under consideration (UNICEF, 2018). The economic crisis not only increased food and non-food prices sharply but further impacted health services, economic and agricultural activities across Sudan. At the end of 2018, living costs were at an all-time high, leading to decreased purchasing power (ACAPS, 2018).

With large imbalances and loose policies, the outlook is alarming without policy reforms. Absent reforms, the weaknesses in competitiveness and in the business environment will persist. GDP growth would then likely remain negative in the near term, with minimal investment and subdued consumption, while bank fragility will rise. High inflation, continued exchange rate depreciation, and pervasive shortages will continue to aggravate social tensions. The fiscal imbalance would also intensify over the medium term, while the current account deficit would remain large, raising risks of disorderly adjustment. Downside risks to the outlook would dominate, albeit with large margins of uncertainty (IMF, 2018).

\section{Analytical Framework and The Results: \\ First: Data Descriptive Statistic (Curves):}

MS

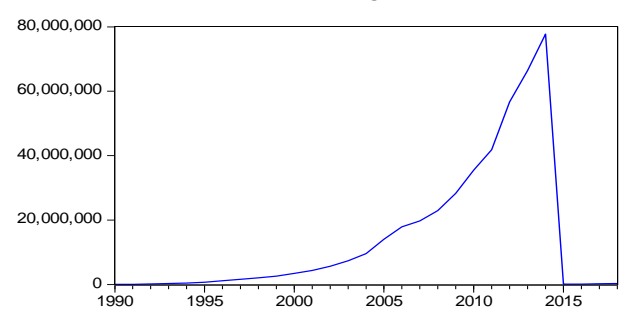

GDP

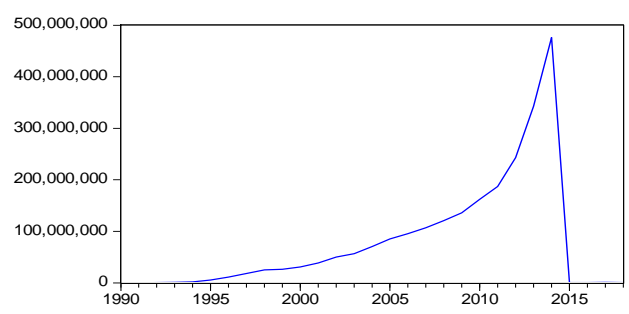

Chart (1)

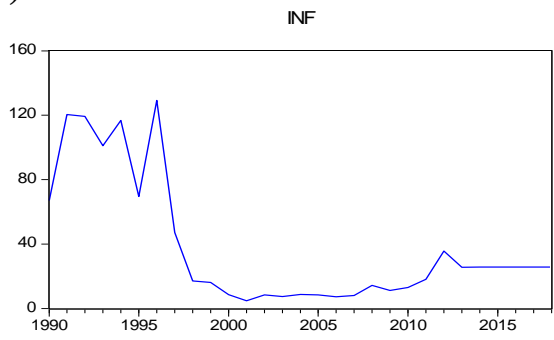

$\mathrm{EXCH}$

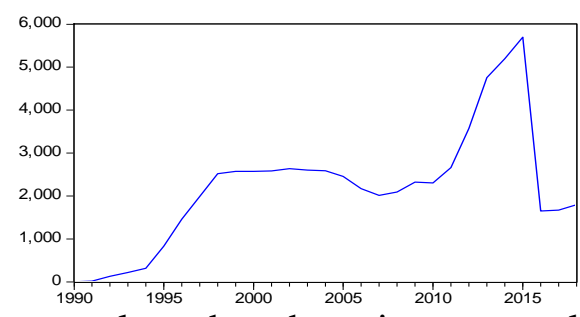

Looking at the chart (1), it becomes clear that there is a general trend towards an increase in the money supply, which calls into question its non staticness, and hence the existence of unity roots. As for the exchange rate, it witnessed stability in the two years (2003-2004) according to (the Comprehensive Peace Agreement). Whereas, the value of the Sudanese pound increased in 2005, due to the implementation of 
the Comprehensive Peace Agreement with the South, and the increase continued to (2006-2007), with the intervention of the Central Bank of Sudan in the market (dealing exchange rates). While the years (20112012) witnessed a sharp decline in the exchange rate as a result of the loss of oil production and its export revenues due to the secession of the South. The decline in the value of the Sudanese pound continued until the year (2017) due to the decrease in productivity, the increase in imports, the accumulation of external debt, and the budget deficit. Inflation recorded stability in the period (2003-2005) as a result of the political stability resulting from the Comprehensive Peace Agreement. Also it decreased in the period (2006-2009) due to the stability of the Sudanese pound, the decrease in the growth of the money supply, and the cessation of military operations. It increased in the period (2010-2017) due to the loss of oil revenues and the weak of production.

From Table (1): It is noted that the average inflation index is less than the average of money supply index, and also when comparing the two mediators, we find that the median of the inflation index is less than the median of money supply, is smaller than the GDP, and the exchange rate. It seems that the inflation index is growing greater than the money supply. The difference was great with comparing the maximum values of: money supply and the exchange rate was approximately four times of inflation. The curvature of the inflation index curve is less than the money supply, GDP, and real exchange rate. The Jarque-Bera value shows that the exchange rate index is closer to a normal distribution dependency. Here we accept the null hypothesis and reject the alternative imposition where the null hypothesis for inflation, money supply, and GDP has been rejected since it does not follow a normal distribution.

Table (1): Descriptive Statistics for The Data

\begin{tabular}{|l|c|c|c|c|}
\hline & MS & INF & GDP & EXCH \\
\hline Mean & $\mathbf{1 4 5 2 2 5 5 4}$ & $\mathbf{3 8 . 3 2 4 1 4}$ & $\mathbf{7 9 1 5 3 1 4 9}$ & $\mathbf{2 1 8 6 . 6 5 9}$ \\
\hline Median & $\mathbf{3 4 6 6 7 0 0}$. & $\mathbf{2 5 . 6 0 0 0 0}$ & $\mathbf{3 1 0 3 7 0 6 8}$ & $\mathbf{2 3 0 5 . 0 0 0}$ \\
\hline Maximum & $\mathbf{7 7 7 3 9 0 0 0}$ & $\mathbf{1 2 9 . 2 0 0 0}$ & $\mathbf{4 . 7 6 E + 0 8}$ & $\mathbf{5 7 0 0 . 0 0 0}$ \\
\hline Minimum & $\mathbf{3 1 6 4 5 . 0 0}$ & $\mathbf{4 . 8 0 0 0 0 0}$ & $\mathbf{1 1 0 1 1 0 . 7}$ & $\mathbf{4 . 5 0 0 0 0 0}$ \\
\hline Std. Dev. & 21565154 & $\mathbf{4 0 . 2 3 0 3 4}$ & $\mathbf{1 . 1 3 E}+08$ & $\mathbf{1 4 0 9 . 1 1 3}$ \\
\hline Skewness & $\mathbf{1 . 6 6 5 3 1 0}$ & $\mathbf{1 . 2 8 2 5 7 0}$ & $\mathbf{2 . 0 4 4 6 8 0}$ & $\mathbf{0 . 5 7 3 4 1 6}$ \\
\hline Kurtosis & $\mathbf{4 . 7 4 4 9 1 8}$ & $\mathbf{3 . 1 1 8 2 1 9}$ & $\mathbf{6 . 9 8 6 2 3 5}$ & $\mathbf{3 . 5 2 8 5 7 8}$ \\
\hline Jarque-Bera & $\mathbf{1 7 . 0 8 3 1 4}$ & $\mathbf{7 . 9 6 7 6 5 8}$ & $\mathbf{3 9 . 4 0 7 3 0}$ & $\mathbf{1 . 9 2 6 8 2 9}$ \\
\hline Probability & $\mathbf{0 . 0 0 0 1 9 5}$ & $\mathbf{0 . 0 1 8 6 1 4}$ & $\mathbf{0 . 0 0 0 0 0 0}$ & $\mathbf{0 . 3 8 1 5 8 8}$ \\
\hline Sum & $\mathbf{4 . 2 1 E}+08$ & $\mathbf{1 1 1 1 . 4 0 0}$ & $\mathbf{2 . 3 0 E + 0 9}$ & $\mathbf{6 3 4 1 3 . 1 0}$ \\
\hline Sum Sq. Dev. & $\mathbf{1 . 3 0 E}+16$ & $\mathbf{4 5 3 1 7 . 4 4}$ & $\mathbf{3 . 5 9 E}+17$ & $\mathbf{5 5 5 9 6 7 9 2}$ \\
\hline Observations & 29 & 29 & 29 & 29 \\
\hline
\end{tabular}

\section{Second: Unit Roots Tests:}

From Table No. (2): the probability value of inflation, GDP, exchange rate, and money supply are less than the level of significance $(5 \%)$, so the null hypothesis has been rejected and accepted the 
alternative one that; there is no unit root for all variables, and therefore the series is static at the first difference. For that, it is noticed; the relationship between the study variables is a logical and not a false one.

Table (2): Dickey Fuller ADF Unit Roots Tests:

\begin{tabular}{|c|c|c|c|c|c|c|c|}
\hline Variable & ADF & Probability & ADF & Probability & ADF & Probability & Order \\
\hline & \multicolumn{2}{|c|}{ Level } & \multicolumn{2}{|c|}{ First Difference } & \multicolumn{2}{|c|}{ 2nd Difference } & \\
\hline INF & $\begin{array}{l}-1.737012 \\
\end{array}$ & 0.4025 & 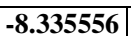 & 0.0000 & & & I(1) \\
\hline $1 \%$ & -3.689194 & & -3.699871 & & & & \\
\hline $5 \%$ & -2.971853 & & -2.976263 & & & & \\
\hline $10 \%$ & -2.625121 & & -2.627420 & & & & \\
\hline MS & -1.972054 & 0.2967 & -5.293079 & 0.0000 & & & I(1) \\
\hline $1 \%$ & -3.689194 & & -3.699871 & & & & \\
\hline $5 \%$ & -2.971853 & & -2.976263 & & & & \\
\hline $10 \%$ & -2.625121 & & -2.627420 & & & & \\
\hline GDP & 3.564271 & 1.0000 & -5.855874 & 0.0000 & & & I(1) \\
\hline $1 \%$ & -3.752946 & & -3.699871 & & & & \\
\hline $5 \%$ & -2.998064 & & -2.976263 & & & & \\
\hline $10 \%$ & -2.638752 & & -2.627420 & & & & \\
\hline EXCH & -2.063541 & 0.2599 & -4.751335 & 0.0000 & & & I(1) \\
\hline $1 \%$ & -3.689194 & & -3.699871 & & & & \\
\hline $5 \%$ & -2.971853 & & -2.976263 & & & & \\
\hline $10 \%$ & -2.625121 & & -2.627420 & & & & \\
\hline
\end{tabular}

Source: Prepared by the researchers from the product of the annexes.

\section{Third: The Co-integration Test:}

The results of the co-integration effect test indicate a rejection of the null hypothesis of the absence of any co-integration vector at a significant level (5\%), and then acceptance of the alternative hypothesis that states there are two equations for the co-integration between the study variables. This indicates that the time series under study are equilibrium in the long run.

Fourth: Estimating The Model:

At this stage, the model variables will be estimated by applying MANOVA and linear regression by the SPSS statistical package to measure the effect of inflation on some macroeconomics indicators in Sudan during the period (1990-2018). (see Appendix, tables 1, 2, 3, ..., and 6).

Table No. (3): The Results of The Co-integration Test (Johansson).

Trace test indicates 2 co-integrating eqn(s) at the 0.05 level

* denotes rejection of the hypothesis at the 0.05 level

**MacKinnon-Haug-Michelis (1999) p-values

Unrestricted Co-integration Rank Test (Maximum Eigenvalue)

\begin{tabular}{|c|c|c|c|c|}
\hline Hypothesized & & Max-Eigen & 0.05 & \\
\hline No. of CE(s) & Eigenvalue & Statistic & Critical Value & Prob.** \\
\hline None $*$ & $\mathbf{0 . 8 7 8 2 7 1}$ & $\mathbf{5 6 . 8 6 0 8 9}$ & $\mathbf{2 7 . 5 8 4 3 4}$ & $\mathbf{0 . 0 0 0 0}$ \\
\hline At most 1 $*$ & $\mathbf{0 . 6 4 9 0 3 1}$ & $\mathbf{2 8 . 2 7 0 5 4}$ & $\mathbf{2 1 . 1 3 1 6 2}$ & $\mathbf{0 . 0 0 4 2}$ \\
\hline At most 2 & $\mathbf{0 . 2 1 9 2 5 2}$ & $\mathbf{6 . 6 8 2 5 8 9}$ & $\mathbf{1 4 . 2 6 4 6 0}$ & $\mathbf{0 . 5 2 7 3}$ \\
\hline At most 3 $*$ & $\mathbf{0 . 2 0 3 4 8 4}$ & $\mathbf{6 . 1 4 2 7 2 3}$ & $\mathbf{3 . 8 4 1 4 6 6}$ & $\mathbf{0 . 0 1 3 2}$ \\
\hline
\end{tabular}


Table (4): Summary of The Results of MANOVA and Linear Regression

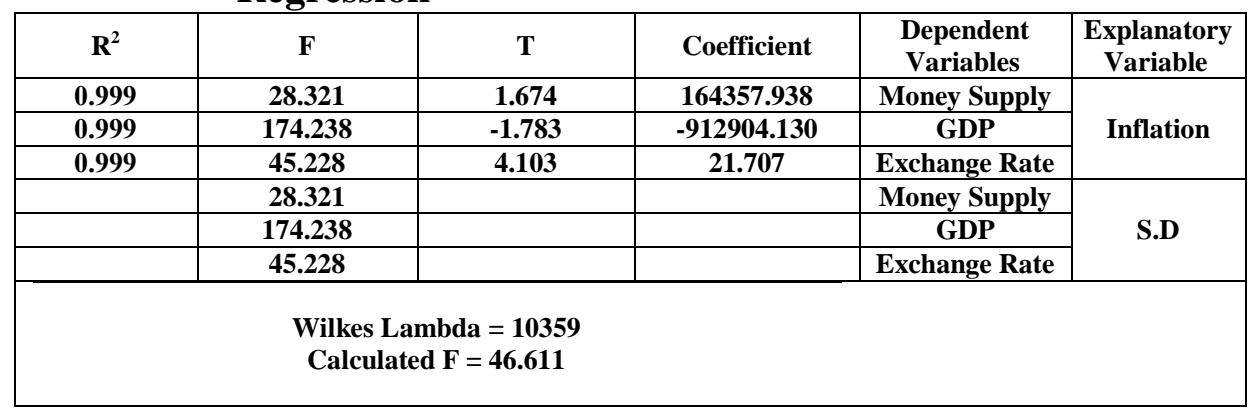

Source: Prepared by the researchers from the product of Appendix No. (4)

Economic Standard:

From the results in table (4), there is a positive relationship among inflation rate and (money supply and the improvement in exchange rate) according to the parameters (164357.94 and 21.71 respectively), and this is completely compatible with economic theory. Increasing inflation reduces the value of the Sudanese pound against foreign currencies and deteriorate exchange rate in Sudan. There is a negative relationship between the rate of inflation and the gross domestic product (according to the parameter -912904.13).

\section{Statistical Standard:}

The probability value associated with (t) test is significant, and this indicates that the variables are affected by each other. Table (4) shows that there are statistically significant differences in the money supply, the exchange rate, and the GDP due to the effect of the inflation rate. The value of the value of Wilkes Lambda (10359), which is a function of the level of significance (0.00). The value of $F$ test (46.611) indicates the existence of differences in the money supply, GDP and exchange rate combined when the effect of inflation, the value of the coefficient of determination $\mathrm{R}^{2}(0.99)$ and this indicates that $99 \%$ of the change in the dependent variables is caused by inflation and $1 \%$ are variables did not included in the model.

Econometrics Standard:

Auto-Correlation Test:

Table (5): Q-Statistic Test

\begin{tabular}{|c|c|c|c|}
\hline Slowdown & Q-Stat & Df & Prop \\
\hline 1 & 197.6300 & 16 & 0.381 \\
\hline 2 & 366.6575 & 32 & 0.410 \\
\hline
\end{tabular}

Source: Prepared by the researchers from Eviews7. 
From the result in table (5) above, it is noticed that the probability value of the autocorrelation test is greater than (0.05), and this indicates that there is no self-correlation problem in the model, which indicates that there is no self-correlation between errors.

Heteroskedasticity Test:

Table (6): Variance Variation

\begin{tabular}{|c|c|c|c|}
\hline F-Statistic & 0.77 & Prop & 0.54 \\
\hline Obs*R-squared & 7.91 & Prop & 0.52 \\
\hline
\end{tabular}

Source: Researchers preparation using E-views

Table (6) classifies the probability values which are associated with the two tests $\mathrm{F}$ and $\mathrm{R}^{2}$ are $(0.54)$ and $(0.52)$ respectively, greater than (0.05), indicating that the model does not suffer from the variance variation problem.

\section{The Main Results:}

1. There is a positive relationship among inflation rate and (money supply and the deterioration in exchange rate) in Sudan.

2. There is a negative relationship between the rate of inflation and the gross domestic product in Sudan.

\section{Recommendations:}

1. To treat the problem of inflation in Sudan, we need to follow a macro policies that lead to increased production.

2. Encouraging local and foreign investment towards productive projects.

3. Interest in the agricultural sector as the backbone of the Sudanese economy.

4. The need to follow urgent monetary and fiscal policies to solve the problem in money supply and the exchange rate in Sudan.

\section{CONCLUSION:}

The study tried to exam the impact of inflation rate on Sudanese economy for the period $(1990$ - 2018). Inflation hit the Sudanese economy for a long years since the begging period after the independence from the British colonialism. There were many causes behind this problem including civil wars, political instability, drought and desertification that struck the country for various years, misuse of resources, and inappropriate macroeconomic policies. The study relied on some assumptions, the most important of them are that: there is a positive relationship between inflation, money supply and the exchange rate. And an inverse relationship between inflation and GDP. The study used the MANOVA method to analyze the data related to the study through the SPSS program. The obtained results proved the validity of the study hypotheses that there is a positive relationship between inflation and the deterioration of the exchange rate, money supply, and an inverse 
relationship with the GDP. The study recommends the need to follow an economic policies that can address the problems of the Sudanese economy, with attention to productive sectors.

\section{REFERENCES:}

Abdulrahman, Badreldin Mohamed Ahmed (2013): Fiscal Policy and Economic Growth in Sudan, 1996-2011. International Journal of Economics, Finance and Management (C2013 http://www.ejournalofbusiness.org, VOL. 2, NO. 8, December 2013 ISSN 2307-2466.

ACAPS Briefing note (2019): Economic Crisis, Sudan. www. acaps.org. Ali, A.A. (1985), "The Sudan Economy in Disarray: Essays on the IMF Model, " Khartoum, Sudan, Ithaca Press, London: Biddies, ISBN-10: 0863720471.

Almosharaf, Haitham Abdualaziz, and Fung Deng Tian (2014): The Causes of Sudan's' Recent Economic Decline. IOSR Journal of Economics and Finance (IOSR-JEF) e-ISSN: 2321-5933, pISSN: School of Economics and Management Lanzhou Jiao tong University, China.

De Gregorio, J. (1993): Inflation, taxation, and long-run growth. Journal of Monetary Economics 31:271-98.

Elbadawi, I.A. and M.S. Kabbashi (2018): The macroeconomics of the gold economy in Sudan. The Economic Research Forum (ERF), 21 Al-Sad Al-Aaly Street, Dokki, Giza, Egypt.

Elhussein, Nawal H. A. and A. E. I. Ahmed (2018): Exchange Rate Volatility in Sudan: Does the Exchange Rate System Matter? Journal of Finance and Bank Management,7(2): 1-24.

Elryah, Yagoub (2016): Sudan's Economic Decline and the Role of Fiscal and Monetary Policies in Sustaining Recovery. Pyrex Journal of Economics and International Finance, 1 (1): 14-19.

Evans Agalega1 and Samuel Antwi (2013): The Impact of Macroeconomic Variables on Gross Domestic Product: Empirical Evidence from Ghana. International Business Research; Vol. 6, No. 5; 2013 ISSN 1913-9004 E-ISSN 19139012, Published by Canadian Center of Science and Education.

Fischer, S., (1993). The role of macroeconomic factors in growth. NBER Working Paper, No. 4565.

Francesco, et al. (2015): Inflation Expectations and Consumption Expenditure. Department for Finance and Banking, Karlsruhe Institute of Technology, Karlsruhe, B-W, Germany. 
Hag Elamin. N.A. and E.M. Elmak. (1997), “Adjustment Programs and Agricultural Incentives in Sudan: A comparative study", AERC Research paper 63. African Economic Research Consortium, Nairobi. In Tomader Gaber ELbashir Elhassan: MEASURE THE IMPACT OF MONETARY POLICY ON ECONOMIC GROWTH IN SUDAN FOR PERIOD 1970-2018. EPRA International Journal of Economic and Business Review-Peer Reviewed Journal SJIF Impact Factor (2019) : 8.045\|.

International Monetary Fund Reports (2019): SELECTED ISSUES ENHANCING GOVERNANCE AND REDUCING THE OPPORTUNITIES FOR CORRUPTION IN SUDAN. PO Box 92780, Washington, D.C. 20090 SUDAN.

Islam, Saleh Mohammed Mashehdul (2009): Exchange Rate and Its Impacts On GDP and Inflation in Bangladesh. ASA University Review, Vol. 3 No. 2, Bangladesh.

Khan, M. (2001): Poverty in the Third World. Discussion Paper. Washington, DC: IMF.

Khan, M.S. and A. Senhadji (2001). Threshold Effects in the Relationship between Inflation and Growth, IMF Staff Papers, 48:1

Kormendi, R. and P. Meguire (1985). Macroeconomic determinants of growth: Cross country evidence. Journal of Monetary Economics, 16 (2): 141-63.

Martin, Rapetti ; Peter Skott and Arslan Razmi (2011): The Real Exchange Rate and Economic Growth: Are Developing Countries Different? Working Paper, UNIVERSITY OF MASSACHUSETTS AMHERST.

Michael Sarel (1995): Nonlinear Effects of Inflation on Economic Growth. Authorized for distribution by Peter Wickham. INTERNATIONAL MONETARY FUND, Research Department, May 1995 WP/95/56 ( IMF WORKING PAPER.

Mohammed A. and et al., (2011): Does Inflation Affect Economic Growth? The case of Pakistan. Pakistan Journal of Social Sciences (PJSS), 31( 1): 51-64.

Mukoka Shame (2018): An Econometric Assessment of the Impact of Inflation on Economic Growth: A Case Study of Zimbabwe Economy. ISSN: 2376 - 659X (Print); ISSN: 2376-6603 (Online), Harare, Zimbabwe. 
Orphanides, A. and R. Solow (1990): Money, inflation and growth, in B. M. Friedman and F. H. Hahn (eds.), Handbook of Monetary Economics, Vol. 1.

Pindyck, R. and A. Solimano (1993): Economic instability and aggregate investment. NBER Working Paper, No. 4380.

Rodrik, D. (2008): The real exchange rate and economic growth, Brookings Papers on Economic Activity, 39, 2, 365-439.

Roubini, N. and X. Sala, Martin (1995): A growth model of inflation, tax evasion and financial repression. Journal of Monetary Economics, 35: 275-301.

Tutor U. (2009): Causes and Effects of Inflation. (www.tutor2u.net>economics).

UNDAF, (2009-2012).United Nations Development Assistance Framework

Zaroog, Ali Elhassan M. N. (2013): Macroeconomic Policies and Economics Growth in Sudan (1970-2005). University of Bakht Alruda Scientific Journal Issue No. 6 May 2013, [ISSN 18586139].

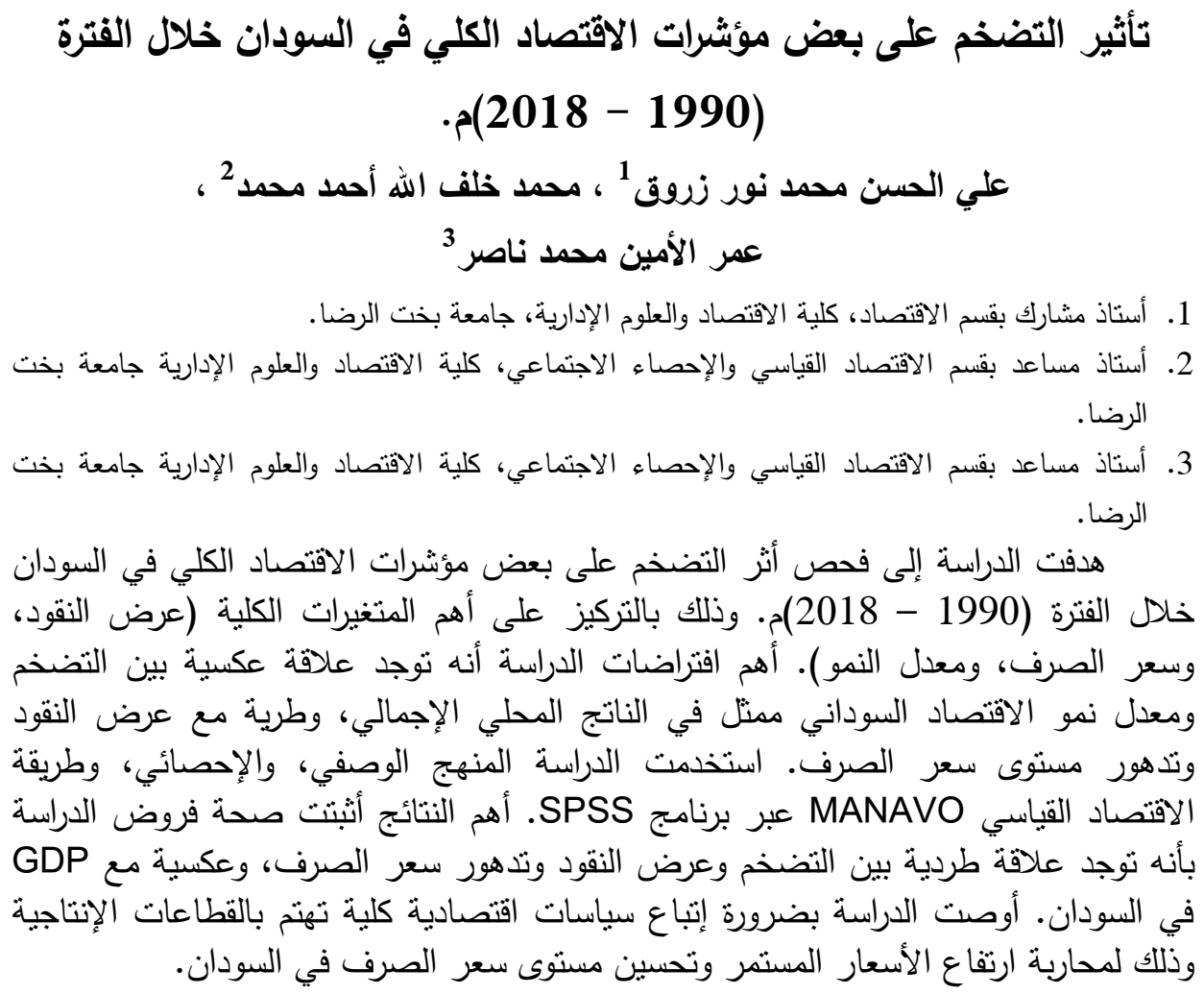




\section{APPENDIX:}

Table (1): GDP, Exchange Rate, Money Supply, and Inflation (Million SD)

\begin{tabular}{|c|c|c|c|c|}
\hline Year & GDP & EXCH & MS & INF \\
\hline 1990 & 110110.7 & 4.500000 & 31645.00 & 67.00000 \\
\hline 1991 & 192060.3 & 15.10000 & 52696.00 & 120.4000 \\
\hline 1992 & 421818.0 & 132.0000 & 141595.0 & 119.3000 \\
\hline 1993 & 948466.0 & 216.0000 & 268583.0 & 101.1000 \\
\hline 1994 & 1881289. & 315.0000 & 405353.0 & 116.8000 \\
\hline 1995 & 5522838. & 832.0000 & 705866.0 & 69.50000 \\
\hline 1996 & 11194938 & 1460.000 & 1166000. & 129.2000 \\
\hline 1997 & 18318179 & 1989.000 & 1597100. & 47.19000 \\
\hline 1998 & 25080913 & 2520.000 & 2069500. & 17.01000 \\
\hline 1999 & 26301423 & 2572.300 & 2579200. & 16.16000 \\
\hline 2000 & 31037068 & 2574.000 & 3466700. & 8.600000 \\
\hline 2001 & 38763329 & 2584.000 & 4322100. & 4.800000 \\
\hline 2002 & 50204397 & 2637.000 & 5632700 . & 8.400000 \\
\hline 2003 & 56720953 & 2602.000 & 7340900 . & 7.400000 \\
\hline 2004 & 70383228 & 2586.000 & 9604500. & 8.700000 \\
\hline 2005 & 85105084 & 2456.000 & 14031400 & 8.400000 \\
\hline 2006 & 95396107 & 2171.000 & $\mathbf{1 7 8 7 1 8 0 0}$ & 7.200000 \\
\hline 2007 & $1.07 E+08$ & 2016.000 & 19714600 & 8.100000 \\
\hline 2008 & $1.21 \mathrm{E}+08$ & 2091.000 & 22933200 & 14.30000 \\
\hline 2009 & $1.36 \mathrm{E}+08$ & 2325.000 & 28314500 & 11.20000 \\
\hline 2010 & $1.62 \mathrm{E}+08$ & 2305.000 & 35497900 & 13.00000 \\
\hline 2011 & $1.87 \mathrm{E}+08$ & 2660.000 & 41853100 & 18.10000 \\
\hline 2012 & $2.43 \mathrm{E}+08$ & 3573.000 & 56663300 & 35.60000 \\
\hline 2013 & $3.43 E+08$ & 4754.000 & 66445700 & 25.60000 \\
\hline 2014 & $4.76 \mathrm{E}+08$ & 5200.000 & 77739000 & 25.70000 \\
\hline 2015 & 582937.4 & 5700.000 & 93642.60 & 25.65000 \\
\hline 2016 & 693514.0 & 1650.900 & 120800.1 & 25.67000 \\
\hline 2017 & 823938.0 & 1672.300 & 203367.5 & 25.66000 \\
\hline 2018 & 758726.0 & 1800.000 & 287312.1 & 25.66000 \\
\hline
\end{tabular}

Source: Bank of Sudan Annual Reports Various Years

Table (2): Coefficients ${ }^{\text {a }}$

\begin{tabular}{|c|c|c|c|c|c|}
\hline \multirow[t]{2}{*}{ Model } & \multicolumn{2}{|c|}{ Unstandardized Coefficients } & \multirow{2}{*}{$\begin{array}{c}\begin{array}{c}\text { Standardized } \\
\text { Coefficients }\end{array} \\
\text { Beta }\end{array}$} & \multirow[t]{2}{*}{$\mathbf{t}$} & \multirow[t]{2}{*}{ Sig. } \\
\hline & B & Std. Error & & & \\
\hline $\begin{array}{c}\text { (Constant) } \\
\text { inf }\end{array}$ & $\begin{array}{c}20821430.083 \\
164357.938\end{array}$ & $\begin{array}{c}5406305.341 \\
98192.484\end{array}$ & .307 & $\begin{array}{l}3.851 \\
1.674\end{array}$ & $\begin{array}{l}.001 \\
060 .\end{array}$ \\
\hline
\end{tabular}

a. Dependent Variable: $\mathrm{ms}$

Table (3)

Coefficients $^{\text {a }}$

\begin{tabular}{|c|c|c|c|c|c|}
\hline \multirow[t]{2}{*}{ Model } & \multicolumn{2}{|c|}{ Unstandardized Coefficients } & $\begin{array}{c}\text { Standardized } \\
\text { Coefficients }\end{array}$ & \multirow[t]{2}{*}{$\mathbf{t}$} & \multirow[t]{2}{*}{ Sig. } \\
\hline & B & Std. Error & Beta & & \\
\hline $\begin{array}{c}\text { (Constant) } \\
\text { inf }\end{array}$ & $\begin{array}{c}114139412.630 \\
-912904.130\end{array}$ & $\begin{array}{c}28197826.194 \\
512145.432\end{array}$ & -.324 & $\begin{array}{l}4.048 \\
-1.783\end{array}$ & $\begin{array}{l}.000 \\
63.0\end{array}$ \\
\hline
\end{tabular}

a. Dependent Variable: gdp 
Table (4)

Coefficients $^{\text {a }}$

\begin{tabular}{|cc|c|c|c|c|c|}
\hline \multirow{2}{*}{ Model } & \multicolumn{2}{|c|}{ Unstandardized Coefficients } & $\begin{array}{c}\text { Standardized } \\
\text { Coefficients }\end{array}$ & \multirow{2}{*}{$\mathrm{t}$} & \multirow{2}{*}{ Sig. } \\
\cline { 3 - 5 } & $\mathrm{B}$ & Std. Error & Beta & & \\
\hline \multirow{2}{*}{1} & (Constant) & $\mathbf{3 0 1 8 . 5 5 1}$ & $\mathbf{2 9 1 . 2 7 3}$ & & 10.363 & .000 \\
& inf & 21.707 & 5.290 & .620 & 4.103 & .000 \\
\hline
\end{tabular}

a. Dependent Variable: exch

Table (5)

Multivariate Tests ${ }^{a}$

\begin{tabular}{|c|c|c|c|c|c|c|}
\hline & Effect & Value & $\mathbf{F}$ & Hypothesis df & Error df & Sig. \\
\hline \multirow{3}{*}{ Intercept } & Pillai's Trace & 1.000 & $10673.555^{b}$ & 2.000 & 1.000 & .007 \\
\hline & Wilks' Lambda & .000 & $10673.555^{b}$ & 2.000 & 1.000 & .007 \\
\hline & Hotelling's Trace & 21347.110 & $10673.555^{b}$ & 2.000 & 1.000 & .007 \\
\hline \multirow{5}{*}{ Inf } & Roy's Largest Root & 21347.110 & $10673.555^{b}$ & 2.000 & 1.000 & .007 \\
\hline & Pillai's Trace & 1.993 & 22.711 & 52.000 & 4.000 & .004 \\
\hline & Wilks' Lambda & .000 & $47.611^{b}$ & 52.000 & 2.000 & .021 \\
\hline & Hotelling's Trace & 10359.938 & .000 & 52.000 & .000 & . \\
\hline & Roy's Largest Root & 10210.635 & $785.433^{c}$ & 26.000 & 2.000 & .001 \\
\hline
\end{tabular}

Table (6)

Tests of Between-Subjects Effects

\begin{tabular}{|c|c|c|c|c|c|c|}
\hline Source & $\begin{array}{c}\text { Dependent } \\
\text { Variable }\end{array}$ & Type III Sum of Squares & Df & Mean Square & $\mathbf{F}$ & Sig. \\
\hline \multirow{3}{*}{$\begin{array}{c}\text { Corrected } \\
\text { Model }\end{array}$} & Ms & $12986292240054090.000^{\mathrm{a}}$ & 26 & 499472778463619.060 & 28.321 & .035 \\
\hline & Exch & $\mathbf{5 5 5 7 2 2 5 7 . 7 2 5}^{\text {b }}$ & 26 & 2137394.528 & 174.238 & 006 \\
\hline & Gdp & $358092237514832700.000^{c}$ & 26 & 13772778365955100.000 & 45.228 & 022 \\
\hline \multirow{3}{*}{ Intercept } & Mis & 6499385731898682.000 & 1 & 6499385731898682.000 & 368.523 & .003 \\
\hline & Exch & 134477312.200 & 1 & 134477312.200 & 10962.462 & .000 \\
\hline & Gdp & 190750300628969984.000 & 1 & 190750300628969984.000 & 626.406 & .002 \\
\hline \multirow{4}{*}{ Inf } & Ms & 12986292240054090.000 & 26 & 499472778463618.900 & 28.321 & .035 \\
\hline & Exch & 55572257.725 & 26 & 2137394.528 & 174.238 & .006 \\
\hline & Gdp & 358092237514832770.000 & 26 & 13772778365955100.000 & 45.228 & 022 \\
\hline & Ms & 35272604192934.580 & 2 & 17636302096467.290 & & \\
\hline \multirow[t]{3}{*}{ Error } & Exch & 24534.145 & 2 & 12267.073 & & \\
\hline & Gdp & 609031102838456.500 & 2 & 304515551419228.250 & & \\
\hline & Ms & 19137797344494480.000 & 29 & & & \\
\hline \multirow[t]{2}{*}{ Total } & Exch & 194259593.650 & 29 & & & \\
\hline & Gdp & 540392676791332100.000 & 29 & & & \\
\hline \multirow{3}{*}{$\begin{array}{c}\text { Corrected } \\
\text { Total }\end{array}$} & Ms & 13021564844247030.000 & 28 & & & \\
\hline & Exch & 55596791.870 & 28 & & & \\
\hline & Gdp & 358701268617671170.000 & 28 & & & \\
\hline
\end{tabular}

a. R Squared $=.997$ (Adjusted R Squared $=.962)$

b. R Squared $=\mathbf{1 . 0 0 0}$ (Adjusted R Squared $=\mathbf{. 9 9 4}$ )

c. R Squared $=.998$ (Adjusted R Squared $=.976$ ) 